\title{
Red tide of Lingulodinium polyedrum (Dinophyceae) in Odesa Bay (Black Sea)
}

\section{Galyna Terenko $^{1, *}\left(\mathbb{D}\right.$, Alexander Krakhmalnyi $^{2}$}

\author{
${ }^{1}$ Ukrainian Scientific Center of Ecology of the Sea, Scientific studies and protection of marine bioceonoses, Odessa, \\ Ukraine \\ ${ }^{2}$ Institute for Evolutionary Ecology National Academy of Science of Ukraine, Kyiv, Ukraine
}

\begin{abstract}
How to cite
Terenko, G., Krakhmalnyi, A. (2022). Red tide of the Lingulodinium polyedrum (Dinophyceae) in Odessa Bay (Black Sea). Turkish Journal of Fisheries and Aquatic Sciences, 22(4), TRJFAS20312. http://doi.org/10.4194/TRJFAS20312
\end{abstract}

\section{Article History}

Received 06 August 2021

Accepted 17 November 2021

First Online 19 November 2021

\section{Corresponding Author}

Tel.: +380974520542

E-mail: terenkogalina@gmail.com

\section{Keywords}

Harmful Algae Bloom

Morphology

Climate changes

Bioluminescence

\begin{abstract}
One of the most massive red tides in Odessa Bay was observed in September-October 2020. It was caused by a toxic dinoflagellate Lingulodinium polyedrum (Stein) Dodge. The maximum abundance $\left(56.1 \times 10^{6}\right.$ cells $\left.L^{-1}\right)$ of $L$. polyedrum was registered the Odessa port area on October 6 , when the water temperature and the salinity were $19.7^{\circ} \mathrm{C}$ and $14.3 \%$, respectively. The red tide was so huge and dense that the water glowed at night due to the bioluminescence characteristic of this species. The article briefly describes the history of the study of $L$. polyedrum in this area and provides a detailed morphological description with original photographs of this species sampled from the bloom. We associate the appearance of the red tide with an increased temperature of sea water and air, a high content of nutrients, the presence of viable L. polyedrum cysts, and a slight decrease in salinity in the bay during the period of a mass development of the species in autumn of 2020. The red tide was accompanied by Protoperidinium steini, $P$. divergens, Prorocentrum cordatum, $P$. minimum, $P$. micans, Gonyaulas scrippsae, Diplopsalis lenticula, Azadinium spinosum, Dinophysis rotundata, D. acuminata, Oblea rotunda, Scrippsiella trochoidea, and Tripos furca.
\end{abstract}

\section{Introduction}

Red tides refer to colour changes of seawater due to the massive development of microscopic planktonic algae. There are more than 300 species of microorganisms that can cause this phenomenon (Harmful Algal Bloom, HAB) and about 80 of them produce highly poisonous toxins (Hallegraeff, 2003). To date, twenty-three toxic and potentially toxic species of dinoflagellates have been found in the Black Sea. Lingulodinium polyedrum is one of them (Ryabushko, 2003; Vershinin et al., 2005).

Lingulodinium polyedrum is a widespread species, and it is capable of yessotoxins production (YTX; Faust \&
Gulledge, 2002; Paz et al., 2004; Paz at al., 2008; Peter at al., 2018). Cases of mass mortality of marine animals in red tide zones caused by $L$. polyedrum have been reported by several authors (Bruno et al., 1990; Turabo et al., 1998).

Red tides caused by mass growth of $L$. polyedrum are periodically found in different parts of the World Ocean. (Amorim et al., 2000; Bennouna et al., 2001; Morales-Ramirez et al., 2001; Salgado et al., 2011).

The species was originally described as Gonyaulax polyedrum (Stein, 1883: Organ. Flagell. 3(2): T. 4, Figure. 7-9). In 1989, it was transferred to the genus Lingulodinium (Wall) Dodge (Dodge, 1989) with the thecal formula: Po, 3', 3a, 6", 6C, S, 6"', 1p, 1'"'. To date, 
a new reinterpretation of the thecal formula of $L$. polyedrum has been proposed as APC (Po), Q, 5', 6", 6C, 6S, 5"', 2"'" (Kim et al., 2005).

The first note of Lingulodinium polyedrum in the Black Sea (as Gonyaulax polyedra) belongs to E. A. Zernov. In October 1909, he observed the appearance of rusty-red stripes caused by L. polyedrum in the coastal zone of Sevastopol (Zernov, 1913).

The abundance of $L$. polyedrum in the Black Sea has been steadily increasing since the 1970 s, L. polyedrum and other resistant to eutrophication species of dinoflagellates, such as Prorocentrum cordatum, P. micans, P. compressum, Scrippsiella acuminata, Heterocapsa triquetra have become the dominant species (Krakhmalnyi et al., 2018).

The first records of red tides in the Black Sea were associated with Prorocentrum cordatum (Skolka \& Gautis, 1969; Nesterova, 1979, 1985, 2001). Since the 1990s, Akashiwo sanguinea, Gymnodinium simplex, Gyrodinium cornutum, G. instriatum, Heterocapsa triquetra, Scrippsiella trochoidea, Prorocentrum cordatum, P. micans and, finally, L. polyedrum have been identified as the main species responsible for red tides in the region (Terenko \& Kurilov, 2001; Terenko \& Terenko, 2009).

The first HAB of L. polyedrum in Odesa Bay was observed near the mouth of the Dnieper-Bug Estuary in October 1999. The abundance of the species was $0,8 \times 10^{6}$ cells $L^{-1}$. This phenomenon was followed by the mass death of fish (Terenko \& Terenko, 2008). HAB of L. polyedrum with abundance of $1,3 \times 10^{6}$ cells $\mathrm{L}^{-1}$ was registered off the Bulgarian coast in the late 1980s to early 1990s (Velikova et al., 1999).

In September-October 2020, one of the biggest red tides in the entire history of the Black Sea studies, caused by L. polyedrum, was observed in Odesa Bay. This dangerous phenomenon was so significant and spectacular that it is still being discussed by the general public (URL-1).

The glow of the water was observed in the dark due to the bioluminescence characteristic of this species, which was repeatedly reported in social media and news (URL-2).

Mass deaths of some marine animals (fish, mollusks) were observed in the red tide zone Odesa Bay, along with the intense coloration of the water and bioluminescence at night. However, Rhizostoma pulmo Macri, Atherina boyeri Risso и A. hepsetu Linnaeus were alive and active inside of the bloom.

\section{Materials and Methods}

Phytoplankton samples were collected from the surface water near the shore at 11 stations located at the Odesa Bay in September-October 2020 (Figure.1). The reverse filtration method was used to concentrate water samples (1.5-2L) and nucleopore filters with a pore size of $1.5 \mu \mathrm{m}$ were applied (Fedorov, 1979; Sorokin, 1979). All samples were condensed to $40-45 \mathrm{~mL}$ and then fixed with a $40 \%$ solution of neutralized formaldehyde to the final concentration of $4 \%$. Subsequently, repeated concretion was carried out, bringing the sample volume to $20-30 \mathrm{~mL}$. Preliminarily, dinoflagellate samples were examined under microscope before fixation with formaldehyde. Quantitative count of cells was carried out in a Nageotte counting chamber with a volume of $0.05 \mathrm{~mL}$ using a light microscope "Mikmed-2" with 300-600X magnification. Calculations of an abundance and a biomass were performed using the DCT software (data collection template) developed in Microsoft Excel, using a Visual Basic script at the Ukrainian Scientific Center of Ecology of the Sea (Odesa).

The morphology of L. polyedrum was studied at the Institute for Evolutionary Ecology National Academy of Sciences of Ukraine, (Kiev) using an Olympus-BX51 microscope. L. polyedrum cells were examined under transmitted light, differential interference contrast (DIC) mode, and fluorescence mode with preliminary staining of thecal plates with Calcofluor White Stain 18909100ML-F (Fritz \& Triemer, 1985). Lenses UPlanFLN $40 \mathrm{x}$ / 0.67, Plan 40 x / 0.65 Ph 2 and Uplan FLN, 100 x /1.30 Oil were used. Cell sizes were determined using the AmScope software. Pictures were taken on Canon EOS $1000 \mathrm{D}$ camera. Images were processed in AdobePhotoshop CS5 Extended. The Statistica program was used to calculate the average cell size and standard deviation. The plates were numbered according to A. Kofoid's system (Kofoid, 1909, 1911), taking into account the reinterpretation of the thecal formula of $L$. polyedrum (Kim et al., 2005).

\section{Results}

\section{Morphological Observation}

Lingulodinium polyedrum (Stein) Dodge, 1989. Bot. Mar. 32: 289, pl. 29, Figure. 1-6. (Figure. 1-12).

Basionym: Gonyaulax polyedra F. Stein 1883. Organ. Infus. 3 (2): Tafel. 4, Figure. 7-9.

Synonyms: Lingulodinium machaerophorum (Deflandre \& Cookson) Wall, Hystrichosphaeridium machaerophor um Deflandre \& Cookson.

References: Paulsen, 1908: 31, Figure 40; Schiller, 1937: 291, Figure 299 a-f; Kiselev, 1950: 222, Figure 386 a-g; Dodge, 1982: 211, Figure. 25 D-F, PI. VI a; Balech, 1988: 170, Figure 17-24; Dodge, 1989: Figure $1 \mathrm{H}, \mathrm{I}, 37-39$; Steidinger \& Tangen 1996: 510, Pl. 43; Faust \& Gulledge, 2002: 45, PI. 29, Figure 1-6; Konovalova \& Selina, 2010: 122, Tabl. XIII, 8 a-b; Krakhmalnyi, 2011: 128, Табл. 32: 1-13; Al-Yamani \& Saburova, 2019: 250, PI. 136.

Description: Cells are angular, pentagonal, with distinct ridges along the intercalary sutures. Epicone and hypocone are almost equal. Epicone has a pointed tip. The plates are strong, with pores and ridges at the seams. The apical pore plate (Po) is oval, surrounded by an elevated ridge. There are five apical plates, $33^{\prime}-5^{\prime}$ separated from Po by the $Q$ plate (equivalent to the $3^{\prime}$ 
plate according to the Kofoidean system). The $Q$ plate is narrow, C-shaped, located between Po and 4' (Figure. $2.3,2.9-2.10)$. The first apical plate (1') contacts with Po (Figure 2.10). A cingulum is equatorial, deep, displaced downward by one or two of its width (Figure. 2.2, 2.7), and composed of plates (6C). A sulcus widens towards the antapex and consists of six plates, the largest being Sp (Figure. 2.4). The hypocone consists of $5^{\prime \prime \prime}$ and two antapical (2'"'). Thecal formula is Po, Q, 5', 6", 6C, 6S, 5'", $2^{\prime \prime \prime \prime}$. The nucleus is in the middle of the cell. Chloroplasts are numerous, oval, yellow-brown in colour, diverging from the center (Figure. 2.1, 2.11). Cells are 33.9-44.5

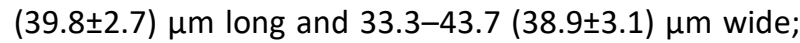
$\mathrm{n}=21$.

Distribution: L. polyedrum is a neritic species commonly occurring in warm temperate to tropical waters of the coastal areas worldwide, bloom-forming species.

Nomenclatural notes: In the Kofoidean system, $1^{\prime \prime \prime}$ is interpreted as 1p (Kofoid, 1909, 1911). We used a reinterpretation of the thecal formula of $L$. polyedrum (Kim et al., 2005). The cell sizes of $L$. polyedrum from the Odesa Bay were in good agreement with the data obtained from Deukryang Bay, Korea (Kim et al., 2005): 32.7-46.2 $\mu \mathrm{m}$ long and 30.4-42.9 $\mu \mathrm{m}$ wide; from Kuwait's waters (Al-Yamani \& Saburova, 2019): 37-42 $\mu \mathrm{m}$ long and 35-39 $\mu \mathrm{m}$ wide and from Caribbean Sea and adjacent area (Wood, 1968): 30-50 $\mu \mathrm{m}$ long.
Under laboratory conditions, vegetative cells produced cysts after storage of samples in the dark at $+5^{\circ} \mathrm{C}$ for 6 days (Figure. 2.12). Cysts are spherical, with a hairy surface, and a noticeable red-brown colour area in the center. Sizes of cysts varied from 43.4 to $45.9 \mu \mathrm{m}$ in diameter.

\section{Quantitative Parameters of the Red Tide of L. polyedrum}

The first detection of L. polyedrum in the plankton of Odesa Bay was recorded in early July 2020 (abundance of $1.2 \times 10^{3}$ cells $\mathrm{L}^{-1}$ ), at a seawater temperature of $22.1^{\circ} \mathrm{C}$ and a salinity of $16.71 \%$. The species had een presented in the plankton for 14 weeks from July to November 2020.

A small growth of $L$. polyedrum was noted at two weekly monitoring areas (Arcadia-Ar and Maliy FontanMF) on September 23. The development was insignificant due to intense water exchange with the open sea at these locations. The maximum abundance was recorded in Arcadia $\left(51.4 \times 10^{3}\right.$ cells $\left.\mathrm{L}^{-1}\right)$ at a seawater temperature of $20.1^{\circ} \mathrm{C}$ and a salinity of $16.4 \%$.

A red tide of $L$. polyedrum was found in Koblevo area (31.17389; 46.62750) during a comprehensive study of Odesa Bay (Figure. 1), conducted from October 1 to October 3, 2020. The abundance of the species was

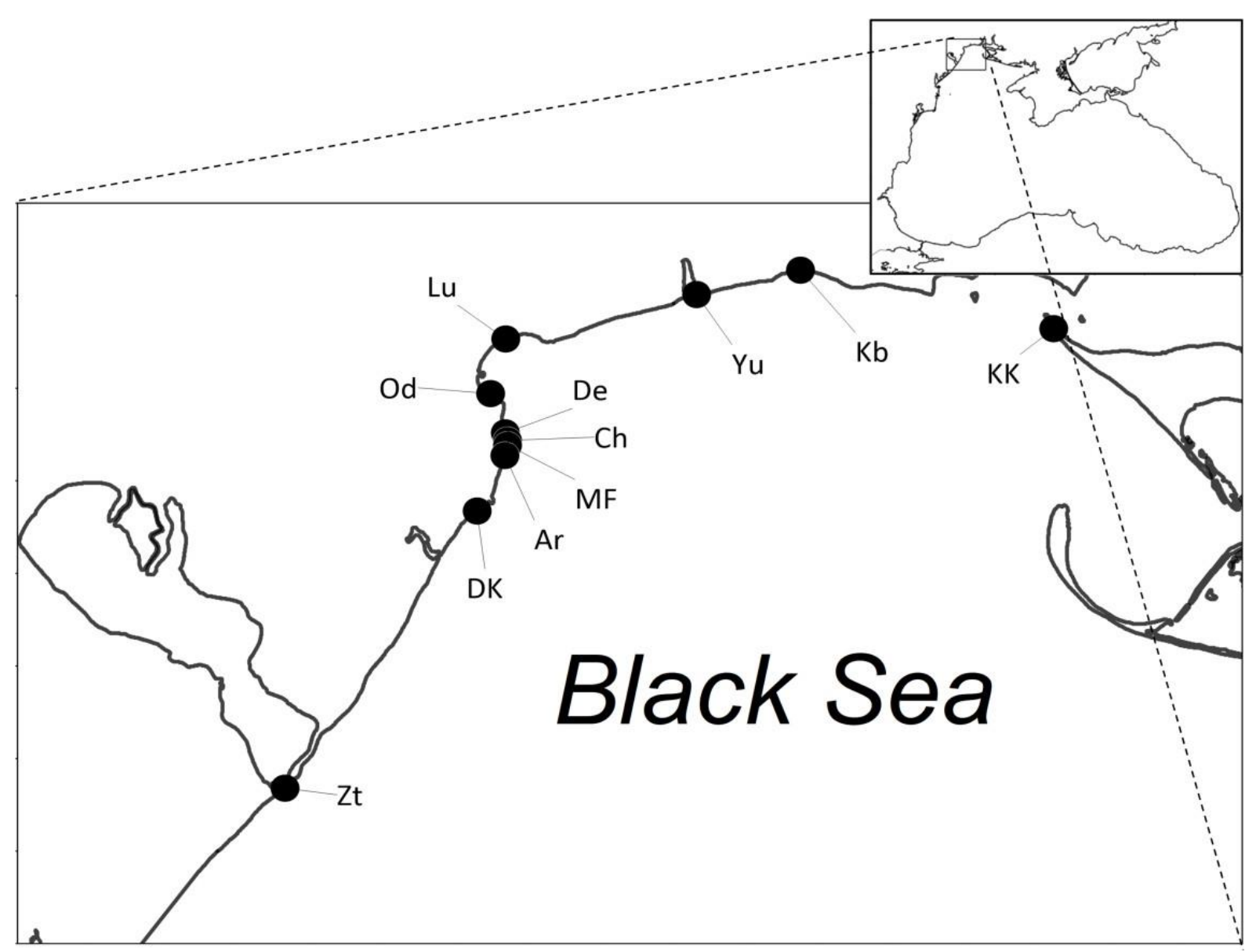

Figure 1. Map of sampling stations at the Odesa Bay in September-October 2020: KK, Kinburn Split; Kb, Koblevo; Yu, Yuzhnoe; Lu, Luzanovka; Od, Port; De, Delphin; Ch, Chkalovskiy; MF, Maliy Fontan; Ar, Arcadia; DK, Dacha Kovalevskogo; Zt, Zatoka 
$1.45 \times 10^{6}$ cells $\mathrm{L}^{-1}$, at a temperature of $20.0^{\circ} \mathrm{C}$ and salinity $13.9 \%$.

The maximum abundances of $L$. polyedrum were recorded in the Odesa Port $(30.74917 ; 46.49417)$ on September 16 with an abundance $9.2 \times 10^{6}$ cells $\mathrm{L}^{-1}$ at a water temperature of $21.7^{\circ} \mathrm{C}$ and salinity $15.9 \%$, and October 6 with an abundance $56.1 \times 10^{6}$ cells $\mathrm{L}^{-1}$ at a water temperature of $19.7^{\circ} \mathrm{C}$ and a salinity of $14.3 \%$. The presence of such high abundances is primarily associated with the "closeness" of this area of the Odesa Bay. It is characterized by a limited water exchange with the open water area of the bay, which contributes to an increase of a trophic state of water.

\section{Discussion}

The red tide of L. polyedrum in the Odesa Bay was provoked by a combination of hydrological and hydrochemical conditions that took place in September-October 2020. Thus, from September 27 to October 2, $17 \mathrm{~mm}$ of precipitation fell in the area of the bay that was half of the October monthly norm (Hydrometeorological Center of the Black and Azov Seas, Odesa, Ukraine). Average monthly air and water temperatures in September-October 2020 significantly exceeded the corresponding average values for the last 30 years (from 1981 to 2010). This excess was $3.2^{\circ} \mathrm{C}$ in
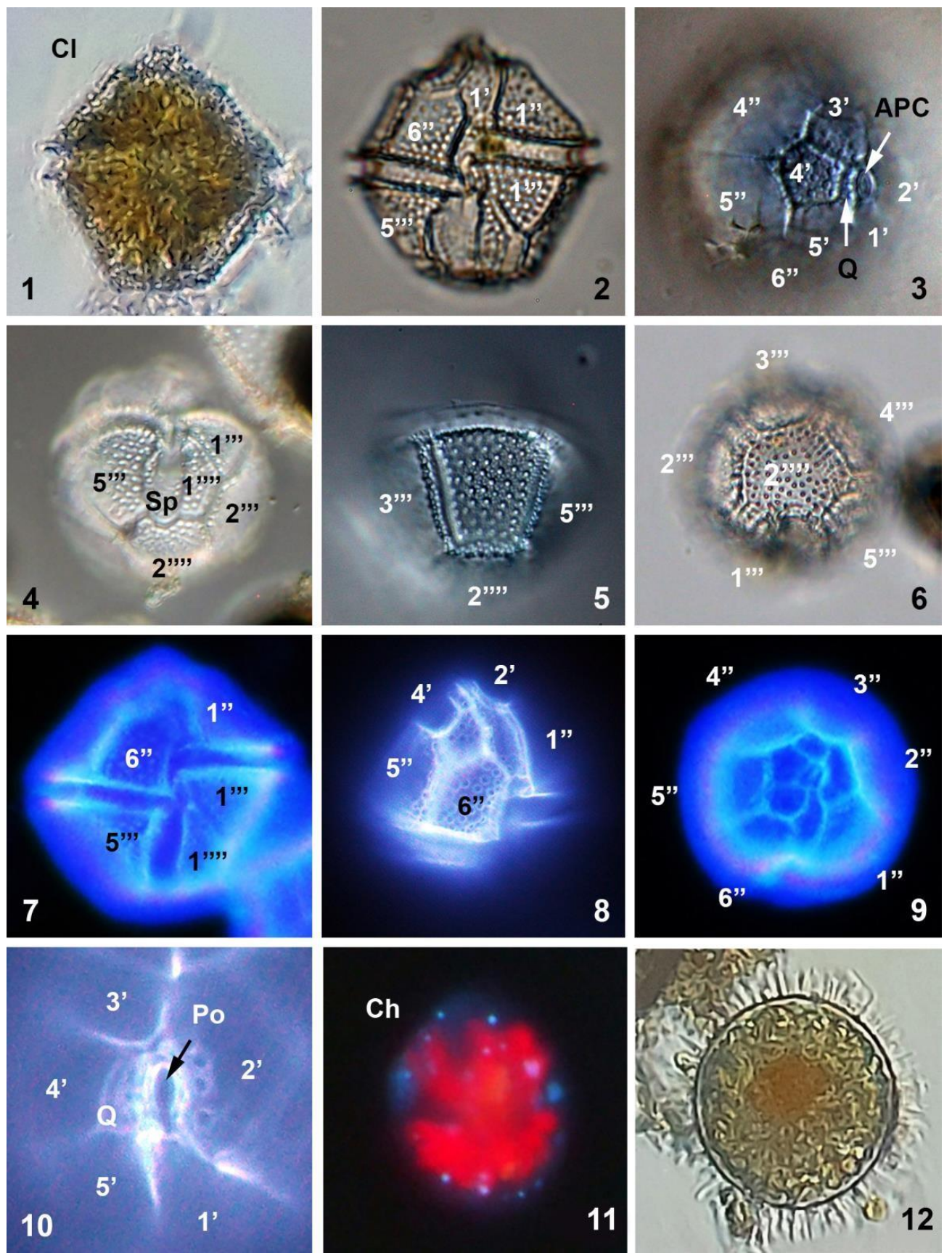

Figure 2. 1-12: Lingulodinium polyedrum (Stein) Dodge. 1-2, 4, 7-8 - ventral view; 6- antapical view (antapex); 3, 9-10- apical view (apex); 5- dorsal view; 3-5- is the differential interference contrast microscopy (DIC); 7-10- a mode of fluorescence with preliminary staining of cells using Calcofluor White M2R. 11- luminescence of chloroplasts in ultraviolet light 12-cyst. Designations: APC - the apical pore complex; Ch- chloroplasts; Po, $Q, 1^{\prime}-5$ ', 1"-6", 1"' -5'", 1'"' -2'"'- thecal plates; Sp-sulcal plate. 1, 12"Mikmed-2" microscope, 2-11- Olympus BX51 microscope. 
September and $5.0^{\circ} \mathrm{C}$ in October for the air temperature. In October, the average monthly air temperature reached a record value of $16.7^{\circ} \mathrm{C}$ for the entire time of observations. In September and October 2020, the mean monthly water temperature in the bay was also higher by $3.4^{\circ} \mathrm{C}$ and $4.4^{\circ} \mathrm{C}$, respectively. Meanwhile, the average monthly water temperature reached a record value of $18.7^{\circ} \mathrm{C}$ in October. In recent years, the coastal regions of the Black Sea have experienced an increase in the air and water temperatures that influence the local ecosystem.

The second important factor contributing to the spread of $L$. polyedrum in Odesa Bay was the wind. Thus, from October 4 to October 6, a southeasterly wind (6-7 $\mathrm{m} \mathrm{x} \mathrm{s}^{-1}$ ) blew in the bay contributing to the surge of the upper layer of seawater with a large number of L. polyedrum cells, into the bay. Wave heights reached $1 \mathrm{~m}$ and they were able to disturb the sediments to a depth of $10 \mathrm{~m}$. This facilitated the migration of dormant L. polyedrum cysts and nutrients from the bottom to the upper layers of the water accelerating the formation of the red tide throughout the bay.

A significantly lower oxygen saturation compared to the previous years was one of the characteristics of the water in autumn 2020. It was about $70 \%$, which is most likely associated with a long period of high temperatures until mid-October (over $20^{\circ} \mathrm{C}$ ) and active destructive processes in the water column.

During our research, L. polyedrum developed in a range of water temperature between $12.5-24.0^{\circ} \mathrm{C}$, salinity between $13.9-16.7 \%$, $\mathrm{pH}$ between $7.69-8.46$,

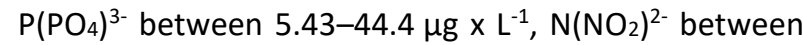
1.51-11.4 $\mu \mathrm{g} \times \mathrm{L}^{-1}, \mathrm{~N}\left(\mathrm{NO}_{3}\right)^{2-}$ between 8.24-146.0 $\mu \mathrm{g} \times$ $\mathrm{L}^{-1}, \mathrm{~N}(\mathrm{NH} 4)^{+}$between $0.26-17.3 \mu \mathrm{g} \times \mathrm{L}^{-1}$, Si between

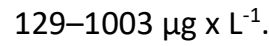

A high abundance of L.polyedrum cysts was revealed by earlier studies of the upper layer of silty sediments in Odesa Bay (Nikonova, 2008; Nesterova, 2010). In our opinion, this fact provided a high rate of biomass growth, even during periods of lower illumination, which took place in early October. As a result, by the end of the active bloom of L. polyedrum (October 6), water samples had a rich dark amber color, which could be explained by the high number of cells. Greasy spots were observed on the surface due to the accumulation of waste products in the water, including lipids of $L$. polyedrum.

\section{Conclusions}

The phenomenon of the red tide had a mosaic nature, with varying degrees of coloration of water in different areas of the bay from light amber to dark amber (amber colours).

As noted above, the red tide in the bay was observed from September 16 to October 6, 2020. At the same time, it was most intense in early October, at a water temperature of $19.7-20.0^{\circ} \mathrm{C}$ and salinity $13.9-$ $15.9 \%$ 。
The development of a red tide in SeptemberOctober 2020 in Odesa Bay was associated with an increased air and water temperature in the autumn of 2020, a sufficient supply of nutrients, winds from the open sea, the presence of viable cysts and a slight decrease in the salinity of water areas where blooming spots were formed.

Other species of dinoflagellates, such as Protoperidinium steinii, P. divergens, Prorocentrum cordatum, P. minimum, P. micans, Gonyaulas scrippsae, Diplopsalis lenticula, Azadinium spinosum, Dinophysis rotundata, D. acuminata, Oblea rotunda, Scrippsiella trochoidea, and Tripos furca were found in smaller numbers in the red tide.

\section{Ethical Statement}

This article does not contain any experiments on humans and animals.

\section{Funding Information}

The work was done under the government funding of Ukraine

\section{Author Contribution}

G.T. contributed to the ecology study of the species A.K. contributed to the morphological study of the species

Writing of the paper was done by both authors in equal part.

\section{Conflict of Interest}

The authors declare that they have no known competing financial or non-financial, professional, or personal conflicts that could have appeared to influence the work reported in this paper.

\section{References}

Al-Yamani, F.Y., Saburova, M.A. (2019). Marine phytoplankton of Kuwait's waters. Volume I. Cyanobacteria, Dinoflagellates, Flagellates.Kuwait Institute for Scientific Research. 468 p.

Amorim, A., Parma, A.S., Sampayo, M.A., Moita M.T. (2000). On a Lingulodinium polyedrum bloom in Setùbal Bay, Portugal. Harmful Algae Blooms. Intergovernmental Oceanographic Commission of UNESCO 2001, 133-136.

Bennouna, A., Berland, B., El Attar, J., Assobhei, O. (2001). Lingulodinium polyedrum (Stein) Dodge red tide in shellfish areas along Doukkala coast (Moroccan Atlantic). Oceanologica Acta 25(3-4): 159-170.

Bruno, M., Gucci, P.M.B., Pierdominici, E., loppolo, A., Volterra L. (1990). Presence of saxitoxin in toxic extracts from Gonyaulax polyedra. Toxicon 28, 1113-1116.

Dodge, J.D. (1989). Some revisions of the family Gonyaulacaceae (Dinophyceae) based on a scanning electron microscope study. Botanica Marina 32, 275 298. 
Faust, M.A. \& Gulledge. R.A. (2002). Identifying harmful marine dinoflagellates. In: Contributions from the United States National Herbarium. Department of Systematic Biology - Botany, National Museum of Natural History, Washington, DC 42, 1-144.

Fedorov V.D. (1979). About methods of studying phytoplankton and its activity. M: From Moscow State University, 168p. (in Russian).

Fritz, L. \& Triemer, R.E. (1985). A rapid simple technique utilizing calcofluor white MR2 for the visualization of dinoflagellate thecal plates. Journal of Phycology 21, 662-664.

Hallegraeff, G.M. (2003). Harmful algal blooms: A Global Overview. In G.M. Hallegraeff, D.M. Anderson, A.D. Cembella (Eds.), Manual on harmful marine microalgae Monographs on Oceanographic Methodology, 2nd Edition, IOC-UNE-SCO, Paris, 25-49.

Kim, K.Y., Yoshida, M., Kim, C.H. (2005). Morphological Variation of Lingulodinium polyedrum (Dinophyceae) in Culture Specimens and Reinterpretation of the Thecal Formula. Algae 20(4), 299-304. https://doi.org/10.4490/algae.2005.20.4.299

Kofoid, C.A. (1909). On Peridinium steini Jörgensen, with a note on the nomenclature of the skeleton of the Peridinidae. Archiv für Protistenkunde 16, 25-47 + 2 pls.

Kofoid, C.A. 1911. Dinoflagella of the San Diego region, IV. The genus Gonyaulax, with notes on its skeletal morphology and a discussion of its generic and specific characters. University of California publications. Zoology 8, 187-286.

Krakhmalnyi, A.F., Okolodkov, Y.B., Bryantseva, Yu.V., Sergeeva, A.V., Velikova, V.N., Derezyuk, N.V., Terenko, G.V., Kostenko, A.G., Krakhmalnyi, M.A. (2018). Revision of the Dinoflagellate species composition of the Black Sea. Algologia 28 (4), 428-448. https://doi.org/10.15407/alg28.04.428

Morales-Ramirez, A., Viquez, R., Rodriguez, K., Vargas, M. (2001). Red tide produced by Lingulodinium polyedrum Peridiniales, Dinophyceae in Baja Culebra, Gulf of Papagayo, Costa Rica. Revista de Biologia Tropical, Suppl. (Supl 2) 49 (Diciembre): 19-23. https://eurekamag.com/research/037/461/037461026. php

Nesterova, D.A. (1979). Development of Exuviaella cordata Ostenfeld and «red tide» phenomenon in the northwestern in the North-Western part of the Black Sea. Biologia Morya 5, 24-29. (in Russian).

Nesterova, D.A. (1985). Mass development of Exuviaella cordata Ostf. and Cerataulina bergonii Perag. in the western Black Sea. Hydrobiology 21(4), 44-65. (in Russian).

Nesterova, D.A. (2001). Water bloom in the north-west part of the Black Sea (review). Algology 11 (4), 502-513. (in Russian).

Nesterova, D.A. (2010). Dormant stages of planktonic algae in the bottom sediments of Odesa Port (Black Sea, Ukraine). Algology 20 (3), 300-311. (in Russian).

Nikonova, S.E. (2008). Comparative analysis of the structure of taxocenotic complexes of cysts of dinophyta algae in the Odesa region. Ecological safety of coastal and shelf zones and integrated use of shelf resources. Collection of scientific papers. Sevastopol 17, 362-370 (in Russian).

Paz, B., Riobó, P., Fernández, M.L., Fraga, S., Franco, J.M. (2004). Production and release of essotoxins by the dinoflagellates Protoceratium reticulatum and Lingulodinium polyedrum in culture. Toxicon 44, 251-
258. https://doi.org/10.1016/j.toxicon.2004.05.021

Paz, B., Daranas, A. H., Norte, M., Riobó, P., Franco, J. M., \& Fernández, J. J. (2008). Yessotoxins, a group of marine polyether toxins: an overview. Marine Drugs, 6(2), 73102. https://doi.org/10.3390/md6020073.

Peter, C., Krock, B., Cembella, A. (2018). Effects of salinity variation on growth and yessotoxin composition in the marine dinoflagellate Lingulodinium polyedra from a Skagerrak fjord system (western Sweden). Harmful Algae 78, 9-17. https://doi.org/10.1016/j.hal.2018.07.001

Ryabushko, L.I. (2003). Potentially harmful microalgae of the Sea of Azov and Black Sea basin. EKOSI-Gidrofizika, Sevastopol, 288 p. (in Russian).

Salgado, P., Troncoso, V.A., Montresor, M., Salamanca, M., Lange, C.B. (2011). First record of Lingulodinium polyedrum (Dinophyceae) resting cysts in coastal sediments from the Inner Sea of Chiloe, Los Lagos Region, southern Chile ( $\left.41^{\circ}-43^{\circ} \mathrm{S}\right) / /$ Gayana Bot. 68(1): 106-109.

Sorokin, Yu.l. (1979). To the method of phytoplankton concentration. Hydrobiology 15(2), 25-30. (in Russian).

Skolka, H., Gautis, J. (1969). Floraizon d'Exuviaela cordata Ostf. et ses consequences sur la peche maritime en Roumania au cours la l'annee. Cercetari Marine 1, 59-82.

Terenko, L.M., Kurilov, A.V. (2001). "Red tides" in the Odesa Bay of the Black Sea. Scientific notes of V. Gnatiuk Ternopol Pedagogic University, Biology Series, Hydroecology, 160-162 (in Russian).

Terenko, L.M., Terenko, G.V. (2008). Long-term dynamics of blooms microalgae in the coast zone of the Odesa Bay (Black Sea), Marine Ecological Journal. 2 (7), 76-86. (in Russian).

Terenko, L.M., Terenko, G.V. (2009). Dynamics of Scrippsiella trochoidea (Stein) Balech 1988 (Dinophyceae) blooms in Odesa Bay of the Black Sea (Ukraine). Oceanology and Hydrobiology Studies 38, 107-112.

Turabo, A., Sidari, L., Loggia, R.D., Yasumoto, T. (1998). Occurrence of yessotoxin-like toxins in phytoplankton and mussels from northern Adriatic Sea. In: B. Reguera, J. Blanco, M.L. Fernandez, T. Wyatt (eds.). Harmful Algae. Xunta de Galicia and Intergovernmental Commission of UNESCO, 470-472.

URL-1 (21 August 2021), https://dumskaya.net/news/krasnyypriliv-odesskiy-zaliv-zapolonili-fotosin-128589/

URL-2 (21 August 2021), http://trassae95.com/all/news/2020/10/10/moresvetitsya-nochjyu-v-odesse-i-predstavlyaet-opasnostjdlya-kupaljcshikov-video-58987.html

Velikova, V., Moncheva, S., Petrova, D. (1999). Phytoplankton dynamics and red tides (1987 - 1997) in the Bulgarian Black Sea. Water Science and Technic 39 (8), 27-36. https://doi.org/10.1016/S0273-1223(99)00184-5

Vershinin, A.O., Moruchkov, A.A., Leighfield, T., Sukhanova, I.N., Pan'kov, S.L., Morton, S.L., Ramsdell, J.S. (2005). Potentially toxic algae in the coastal phytoplankton of the northeast Black Sea in 2001-2002. Oceanology 45 (2), 224-232.

Wood. E. J. F. (1968). Dinoflagellates of the Caribbean Sea and adjacent areas. University of Miami Press. Coral Gables. Florida. $142 \mathrm{p}$.

Zernov, S.A. (1913). About the study of the life of the Black Sea. West Imp. Academic sciences in physics and mathematics 32(1). 299 p. (in Russian). 